\title{
A!
}

This is an electronic reprint of the original article.

This reprint may differ from the original in pagination and typographic detail.

Tervo, Juuso

\section{Sacrifices, or Creating Destruction}

Published in:

Art Education

DOI:

$10.1080 / 00043125.2019 .1648145$

Published: 07/10/2019

Document Version

Peer reviewed version

Published under the following license:

Unspecified

Please cite the original version:

Tervo, J. (2019). Sacrifices, or Creating Destruction. Art Education, 72(6), 41-43.

https://doi.org/10.1080/00043125.2019.1648145

This material is protected by copyright and other intellectual property rights, and duplication or sale of all or part of any of the repository collections is not permitted, except that material may be duplicated by you for your research use or educational purposes in electronic or print form. You must obtain permission for any other use. Electronic or print copies may not be offered, whether for sale or otherwise to anyone who is not an authorised user. 
Sacrifices, or Creating Destruction

Juuso Tervo

Aalto University

Author note:

Juuso Tervo, University Lecturer, Director of University-Wide Art Studies

School of Arts, Design and Architecture, Aalto University

Correspondence concerning this article should be addressed to:

Juuso Tervo, School of Arts, Design and Architecture, Aalto University

PO Box 31000, FI-00076 Aalto

Espoo, Finland

Contact: juuso.tervo@aalto.fi

Words: 1960 
Running head: SACRIFICES

Abstract

This commentary article addresses the relationship between art education, entrepreneurship and creative destruction by critically exploring the logic of historical progress that the notion of creative destruction entails. The central argument of the article is that Eurocentric calls for progress have been often paired with the figurative or actual destruction of what is claimed to hinder this progress, including non-Western cultures. Taking William Torrey Harris (18351909), a philosopher of education and the Commissioner of the U.S. Bureau of Education, as an example of this logic, the article calls for an approach to creative destruction in art education that is sensitive to past destructions upon which the future, as well as the present, might be built.

Keywords: history of art education; William Torrey Harris; recapitulation theory; decolonial history 


\section{SACRIFICES}

\section{Sacrifices, or Creating Destruction}

\section{$<$ INSERT FIGURE 1 HERE $>$}

To understand destruction as a force of creation is to partake in a complex and multifarious tradition of thought. In many Indo-European cosmogonies, for example, a mythical event of sacrifice, like the killing of Ymir in Norse mythology, gives shape to the current order of the world: the sky and celestial bodies above, the earth below, and the seas surrounding the land. Often these sacrificial scenes of creation are paired with visions of another destructive event waiting in the future - the end of the world, Ragnarök for the Norse - which eventually destroys the world once created for humans to dwell. ${ }^{1}$

Without trying to mythologize or essentialize the theme of this special issue, entrepreneurship and creative destruction, the purpose of this short commentary is to offer an approach to creative destruction that is sensitive to past destructions upon which the future, as well as the present, might be built. What interests me about creative destruction is a peculiar entanglement of an end and a beginning, a change of epoch where a new world rises from the ruins of the old. Traditionally, the power to induce historical changes has been traditionally reserved only for exceptional, god-like figures. Today, one finds artists, educators, and entrepreneurs separating our societies from past and present burdens, eventually leading us to a better future: “America's arts industry is not only resilient in times of economic uncertainty, but is also a key component to our nation's economic recovery and future prosperity" (Lynch, 2013, np.).

What does it mean to be associated with such power to break out from the chains of the present? And what kind of sacrificial violence, figurative or actual, might it entail?

The amalgamation of art, education, and economics has been part of art education's future-orientated imaginaries at least since its inclusion in public schools in the United States 


\section{SACRIFICES}

in the late 19th century. Back then, the idea that the growing industry needed to produce things that were not only functional and efficient, but beautiful and desirable as well, was clearly present in art education literature (cf. Clarke, 1885; Nichols, 1877). In the words of William Torrey Harris (1835-1909), a philosopher of education and the Commissioner of the U.S. Bureau of Education from 1889 to 1906: "[W]ealth demands the aesthetic. The days of poverty may be satisfied with the useful" (Harris, 1897, p. 60). The societal mission of art education seemed clear: it relocated the forces of beauty and order from the allegedly esoteric realm of the fine arts to the public use of the people. Only then could economy and democracy truly flourish, both today and tomorrow.

No sacrifices thus far, it seems. But clearly the days of poverty, when mere useful is enough, must pass.

Like all histories, this is merely one (hi)story of art education's past. Arthur Efland and Donald Soucy (1991) have argued that a historiographical emphasis on figures like Isaac Edwards Clarke, a prolific advocate of industrial drawing who worked for the Bureau of Education during the last decades of the 19th century (also under Harris), has produced fairly narrow histories portraying "a handful of enlightened businessmen and educators as determining art education's fate, foisting it on a passive population” (p. 510). More recently, Mary Ann Stankiewicz (2017) has criticized the tendency in art education histories to focus merely on "nineteenth-century Massachusetts policy makers and the White men and women with British and European ancestry who introduced drawing to the common school," arguing that we must question "assumptions that institutions, such as public schools, offering formal instruction in the arts are and should be the norm" (p. 9).

While certainly limited and partial ${ }^{2}$, this (hi)story not over. Connecting artistic activities - whether in education or economics or both - to economic prosperity continues to be part of art education advocacy, especially when envisioning futures that the present ought 


\section{SACRIFICES}

to unfold (cf. National Art Education Association, 2016). In this respect, the exclusionary practices Stankiewicz points to - namely, divisions based on class, race, and gender - are not issues that concern merely art education historians who wish to understand past events. They are part of a (hi)story in the making, constantly shaping the futures presented as cures for present ills.

In order to better understand this (hi)story and its exclusions, both past and present, I will take a closer look at William Torrey Harris's views on art, education, and historical progress. This is not because I consider Harris as an exceptional individual who has determined the fate of the field - to keep up with the critiques above - but because his direct involvement with federal policies allows situate his words within a larger societal frame of the late 19 th century. As I will show, the entwinement of artistic, educational, and economic growth he presents includes a destructive side that forces us to ask, whose future are we talking about when are revering of a better world, and who may be sacrificed for the sake of it.

As a prominent philosopher of education, Harris was well versed in European and North American thought. One of the frameworks he drew from was recapitulation theory, which was based on an idea that "the development of the individual retraced the cultural history of the human race and that non-White cultural groups represented an earlier, inferior, and childlike status" (Fallace, 2012, p. 511). This approach resonates with his views on art as well. Like many of his fellow contemporaries, Harris turned to ancient Greece as an exemplary case of a beautiful, well-functioning society. "Greek art has become the conventional expression of the beautiful for all the civilized world," he claimed, arguing that "it alone aims at the expression of personal freedom in the body, and therefore always achieves gracefulness" (Harris, 1897, p. 77). The aesthetic that wealth demanded was not, then, any kind of aesthetic. As the mythic place of origin of Western civilization, ancient 


\section{SACRIFICES}

Greece offered a model for societal order and harmony that separated the history of Western progress from other, non-European civilizations such as India: "Nothing that has form, or shape, or properties, or qualities - nothing, in short, that can be distinguished from anything else, can be divine according to the thought of the Hindoo" (p. 72). In other words, there were two histories for Harris: Western and non-Western, and only the former led to a desirable future.

Taking this into consideration, it should not come as a surprise that Harris was also an advocate of the boarding school system for the American Indigenous peoples. He argued that, "we owe it to ourselves and to the enlightened public opinion of the world to save the Indian, and not destroy him. We can not save him and his patriarchal or tribal institution both together. To save him we must take him up into our form of civilization" (Harris, 1890, p. 5). Not to destroy, but to save - on one condition: The Indigenous body was to be uprooted, with the help of education, from a culture that allegedly tied it to the past and be brought inside the epochal bounds of European history. If this condition was not met by the Indigenous, they were to face total destruction:

while the patriarchal or tribal form exists our own civilization must protect itself from the dangers which menace it from that lower form of civilization by supporting military forces or an armed police on the tribal frontiers. This looks towards a continual heavy expense, or, on the other hand, towards the cruel policy of extermination. (p. 4)

So, what Harris teaches us about creative destruction? While his words may seem distant today, I do not believe he should be treated merely as a historical peculiarity who belongs to an earlier stage in the development toward a more civilized and just society. This would require, after all, that one agreed with his narrative of progression. Harris simply articulated a will to induce harmony and order where they did not seem to exist; a will resonating with how individuals and communities are asked to live up to their fullest potential in order assimilate into the so-called economic realities of today. What Harris's words show is 


\section{SACRIFICES}

that the seemingly disorganized lives of those who do not find their place in a universalized narrative of progression can be sacrificed for the sake of the future. In this narrative, untimely lives become remnants - sometimes exoticized, sometimes ridiculed, sometimes demonized of a past constructed by those who claim the present and the future to themselves. Ultimately, a new order springs from past disorder, as when a gentrifier is happy to find yet another cool coffee shop opening in the neighborhood.

In mythologies, shifts in the order of time often mark the end of world. Then, the dead rise from their graves, and primordial monsters return to destroy the world built on their remains. In today's economic parlance, similar dark clouds of destruction serve as an efficient way to justify the allegedly necessary sacrifices to be made for the sake of continuous economic growth. Harris, speaking from the past in the present, demonstrates that such terrible events are not merely looming in the future, but may already be here, often intimately connected to (hi)stories of progression narrated by those in power.

When exploring futures imagined in the intersection of art education, entrepreneurship, and creative destruction, I see that it is important to pay attention to whose future is at stake and in what ways. Rather than constantly creating destruction in the name of something seemingly new, one might learn from other (hi)stories of art and education. I am thinking particularly those that have been excluded from the futures envisioned by those who claim the future to themselves. These other (hi)stories, ceaselessly in the making, point to ways of living, learning, and teaching that may challenge universalized narratives of progress based on a single story. They are not made somewhere else - spatially or temporally - but here and now, including classrooms, museums, institutions, and communities where art educators do their work. To be sensitive to their making is, I claim, an ethical task: it contests the seeming necessity of art education's fate, and opens the past, the present, and the future not to various acts destruction, but of creation. 


\section{SACRIFICES}

\section{References}

Clarke, I. E. (1885). Art and industry. Education in the industrial and fine arts in the United States. Part 1. Drawing in public schools. Washington, D.C.: Government Printing Office.

Efland, A., \& Soucy, D. (1991). A persistent interpretation: Art education historiography and the legacy of Isaac Edwards Clarke. History of Education Quarterly, 31(4), 489-511.

Fallace, T. (2012). Recapitulation theory and the new education: Race, culture, imperialism, and pedagogy, 1894-1916. Curriculum Inquiry, 42(4), 510-533.

Harris, W. T. (1890). Introduction. In T. J. Morgan, Indian Education (pp. 3-5). Washington, D.C: Government Printing Office.

Harris, W. T. (1897). Art education. The true industrial education (2nd ed.). Syracuse, NY: C. W. Bardeen.

Lynch, R. L. (2013). The arts mean business. In Arts and economic prosperity IV. The economic impact of nonprofit arts and culture organizations and their audiences. Retrieved from

https://www.americansforthearts.org/sites/default/files/pdf/information_services/research/serv ices/economic_impact/aepiv/NationalStatisticalReport.pdf

National Art Education Association (2016). Learning in a visual age. The critical importance of visual arts education. Retrieved from https://arteducatorsprod.s3.amazonaws.com/documents/729/2b07a08f-edc2-40f1-b9a87c61e84adc42.pdf?1469139315

Nichols, G. W. (1877). Art education applied to industry. New York, NY: Harper \& Brothers. 


\section{SACRIFICES}

Stankiewicz, M. A. (2017). Foreword. In P. E. Bolin \& A. Kantawala, Revitalizing History (pp. 9-12). Wilmington, DE: Vernon Press.

\section{Figure Captions}

Figure 1. Louis Moe, Ragnarok (1891) from Danmarks Historie i Billeder (1898),

Copenhagen, Denmark. Color lithography on paper, 12.7 x 16.3 in. Source:

https://commons.wikimedia.org/wiki/File:Ragnarok_(17006).tif. Copyright: This work is in the public domain in the United States because it was published (or registered with the U.S. Copyright Office) before January 1, 1924.

${ }^{1}$ In Norse mythology, Ragnarök is succeeded by a new world inhabited by two humans. Yet again, destruction and creation are entwined.

${ }^{2}$ Notably, this (hi)story itself is not one: the late 19th century literature discussing the relationship between art education and industry portrays an array of approaches to beauty, harmony, and order. For example, Efland and Soucy (1991) argue that Clarke's views differed from Harris's on these matters. 